\title{
Psychosocial Adjustment, Depression, Anxiety, and Stress in Pregnancy Following Assisted Reproductive Treatment and Spontaneous Conception
}

\author{
Yardımcı Üreme Tedavi ve Spontan Gebelik Sonrası Kadınların Gebeliğe \\ Uyumları, Depresyon, Anksiyete ve Stres Durumlarının Karşılaştırılması
}

(i) Șükran BAȘGÖL

Avrasya University Faculty of Health Sciences, Midwifery Department, Trabzon, Turkey

\section{ABSTRACT}

Objective: This study aimed to determine the psychosocial adjustment, depression, anxiety, and stress levels between women who conceived through assisted reproductive treatment (ART) and women who were fertile and conceived spontaneously.

Methods: This prospective, comparative, and descriptive study enrolled 69 women who presented to İstanbul University's İstanbul Medical Faculty Reproductive Endocrinology and Infertility Department and conceived through ART between June 2015 and June 2016 and 139 women who presented to the antenatal policlinic for pregnancy. Data were obtained using the Personal Identification Form, Prenatal Self-Evaluation Questionnaire, and Depression, Anxiety, And Stress scale in each trimester.

Results: The adaptation of spontaneously pregnant women (spontaneous group) was better than that of women who became pregnant by ART (ART group) in the first trimester. The psychosocial adjustment of all women to pregnancy was the highest in the second trimester, followed by the third and first trimesters. Infertility time, infertility treatment duration, number of ART attempts, duration of wanting to have a child, pregnancy loss experience, and cause of infertility did not affect pregnancy adjustment in all trimesters. In the first and third trimesters, depressive symptoms are more common in the spontaneous group than in the ART group. In the first and third trimesters, the anxiety and stress levels were higher in the ART group than in the spontaneous group.

\section{ÖZ}

Amaç: Üremeye yardımcı tedavi uygulamaları (ÜYTU) sonrası gebe kalan kadınlar ile spontan gebe kalan kadınların, gebeliğe uyumları ile depresyon, anksiyete ve stres durumlarını belirlemektir.

Yöntemler: Prospektif tipte, karşılaştırmalı-tanımlayıcı bir araştırmadır. Araştırmaya Haziran 2015-2016 tarihleri arasında İstanbul Üniversitesi İstanbul Tip Fakültesi Üreme Endokrinolojisi ve İnfertilite Anabilim Dalı'na başvuran ve ÜYTU ile gebe kalan 69 kadın ile doğum öncesi polikliniğine başvuran spontan gebe kalan 139 kadın dahil edilmiştir. Veriler; Tanıtıcı Bilgi Formu, Prenatal Kendini Değerlendirme Ölçeği, Depresyon-Anksiyete-Stres Ölçeği uygulanarak her üç trimesterde elde edilmiştir. Analizlerde sayı, yüzde, ortalama, standart sapma, ki-kare, bağımsız örneklem t testi ve tek yönlü varyans analizi kullanılmıştır.

Bulgular: Spontan gebe kalan kadınların gebeliğe uyumları birinci trimesterde ÜYTU sonrası gebe kalan kadınlara göre daha iyi düzeyde olduğu belirlenmiştir. Tüm kadınların gebeliğe psikososyal uyumu en fazla ikinci trimesterde iken; bunu üçüncü ve birinci trimester izlemiştir. İnfertilite süresi, infertilite tedavi süresi, ÜYTU deneme sayısı, çocuk sahibi olma isteme yılı, gebelik kaybı deneyimi ve infertilite nedeni değişkenlerinin her üç trimesterde de gebeliğe uyumu etkilemediği belirlenmiştir. Spontan gebe kalan kadınlarda depresif belirtiler birinci ve üçüncü trimesterde ÜYTU sonrası gebe kalan kadınlara kıyasla daha fazla iken, ÜYTU sonrası gebe kalan kadınlarda anksiyete ve stres belirtileri birinci ve üçüncü trimesterde
Address for Correspondence: Şükran BAŞGÖL, Avrasya University Faculty of Health Sciences, Midwifery Department, Trabzon, Turkey

E-mail: sukran.basgol@avrasya.edu.tr ORCID ID: orcid.org/0000-0003-3842-4557
Received: 10.07.2020

Accepted: 19.11.2020

Cite this article as: Başgöl Ş. Psychosocial Adjustment, Depression, Anxiety, and Stress in Pregnancy Following Assisted Reproductive Treatment and Spontaneous Conception. Bezmialem Science 2021;9(4):457-64. 
Conclusion: Psychosocial support programs should be organized for women who conceived through ART in infertility clinics. Moreover, routine pregnancy monitoring should cover the psychosocial evaluation of pregnant women, including adjustment, depression, anxiety, and stress.

Keywords: Psychosocial adjustment, assisted reproductive treatment methods, depression, anxiety, stress spontan gebe kalan kadınlara kıyasla daha fazla olduğu saptanmıştır.

Sonuç: İnfertilite kliniklerinde ÜYTU ile gebe kalan kadınlara psikososyal destek programları düzenlenmelidir. Ayrıca kadınların rutin gebe izlemleri psikososyal değerlendirmeyi de (uyum, depresyon, anksiyete, stres) kapsamalıdır.

Anahtar Sözcükler: Psikososyal uyum, üremeye yardımcı tedavi uygulamaları, depresyon, anksiyete, stres

\section{Introduction}

Infertility is defined as the absence of pregnancy despite regular sexual intercourse for at least 1 year without any contraceptive method (1). Infertility is not only a gynecological disorder but also a health problem that has negative biological, social, cultural, and psychological dimensions and can affect the couples' quality of life (2). Pregnancy is considered a physiological event in the life of the woman and an important life event that requires serious biopsychosocial adaptation by the pregnant woman and her family. Many studies have defined the pregnancy period as a developmental crisis or a critical phase. While many women easily adapt to the physiological, psychological, and social changes caused by pregnancy, some may have psychological illnesses at mild, moderate, and severe levels. Especially, in women who conceived for the first time after infertility treatment, this process is described as a psychological risk, stressful, and expensive (3-5).

Studies have suggested that many women with infertility who conceived after chronic infertility treatment do not have the chance to renew their psychological resources that were consumed during the treatment process and have a more difficult experience with the pregnancy process and parenting roles and therefore need more support $(6,7)$. Similar studies have reported that women who conceived for the first time following infertility treatment had a higher level of stress, had difficulty adapting to the pregnancy, and experienced lower psychological well-being than women who became pregnant spontaneously (8-11).

Considering that women who conceived after infertility treatment have attained their desired pregnancy, health workers may overlook or care less about the negative emotional situations of pregnant women. Some pregnant women may have difficulty recognizing the negative symptoms they have experienced. Others may be ashamed of expressing negative symptoms after their long struggle to having a baby, while some may disagree when they learn about symptoms of maladaptation, depression, anxiety, or stress. Although infertility treatment may result in pregnancy, women's adaptation to pregnancy and their emotional states may be affected. Therefore, health professionals should evaluate the adaptation of women to pregnancy and examine their depression, anxiety, and stress situations. Some studies about adaptation to pregnancy have been performed in Turkey, but they do not include the three trimesters or comparative groups $(7,12,13)$.

\section{Subjects and Methods}

This prospective, comparative, and descriptive study focused on women who presented to İstanbul University, İstanbul Medical Faculty Reproductive Endocrinology and Infertility Department and conceived through assisted reproductive treatment (ART) and all women who presented to the antenatal polyclinic for pregnancy follow-up between June 2015 and June 2016. The study sample consists of women who participated in the study voluntarily and met the inclusion criteria. Of these women, 69 conceived through ART and 139 conceived spontaneously (Figure 1).

Ethical approval was obtained from the Ethics Committee of Medipol University Faculty of Medicine (approval no: 108400987-292, date: 11.05.2015).

Women aged $>18$ years who were in the first trimester of pregnancy, were not diagnosed with any psychiatric illness, had no symptoms indicative of fetal illnesses, do not have any literacy problem, did not have mental or communication disorder, volunteered to participate in the study, conceived for the first time through at least one of the ARTs (ART group), and conceived naturally without any treatment for the first time (spontaneous group) were included in this study.

Infertility is defined as the absence of pregnancy despite regular sexual intercourse for at least 1 year without any contraceptive method (1). Infertility is not only a gynecological disorder but also a health problem that has negative biological, social, cultural, and psychological dimensions and can affect the couples' quality of life (2). Pregnancy is considered a physiological event in the life of the woman and an important life event that requires serious biopsychosocial adaptation by the pregnant woman and her family. Many studies have defined the pregnancy period as a developmental crisis or a critical phase. While many women easily adapt to the physiological, psychological, and social changes caused by pregnancy, some may have psychological illnesses at mild, moderate, and severe levels. Especially, in women who conceived for the first time after infertility treatment, this process is described as a psychological risk, stressful, and expensive (3-5).

Studies have suggested that many women with infertility who conceived after chronic infertility treatment do not have the chance to renew their psychological resources that were consumed during the treatment process and have a more difficult 
experience with the pregnancy process and parenting roles and therefore need more support $(6,7)$. Similar studies have reported that women who conceived for the first time following infertility treatment had a higher level of stress, had difficulty adapting to the pregnancy, and experienced lower psychological well-being than women who became pregnant spontaneously (8-11).

Considering that women who conceived after infertility treatment have attained their desired pregnancy, health workers may overlook or care less about the negative emotional situations of pregnant women. Some pregnant women may have difficulty recognizing the negative symptoms they have experienced. Others may be ashamed of expressing negative symptoms after their long struggle to having a baby, while some may disagree when they learn about symptoms of maladaptation, depression, anxiety, or stress. Although infertility treatment may result in pregnancy, women's adaptation to pregnancy and their emotional states may be affected. Therefore, health professionals should evaluate the adaptation of women to pregnancy and examine their depression, anxiety, and stress situations. Some studies about adaptation to pregnancy have been performed in Turkey, but they do not include the three trimesters or comparative groups $(7,12,13)$.

\section{Subjects and Methods}

This prospective, comparative, and descriptive study focused on women who applied to İstanbul University, İstanbul Medical Faculty Reproductive Endocrinology and Infertility Department and conceived through ART and all women who presented to the antenatal polyclinic for pregnancy follow-up between June 2015 and June 2016. The study sample consists of women who participated in the study voluntarily and complied with the research criteria. Of these women, 69 conceived through ART and 139 conceived spontaneously (Figure 1).

Ethical approval was obtained from the Ethics Committee of Medipol University Faculty of Medicine (approval no: 108400987-292, date: 11.05.2015).

Women aged $>18$ years who were in the first trimester of pregnancy, were not diagnosed with any psychiatric illness, had no symptoms indicative of fetal illnesses, do not have any literacy problem, did not have mental or communication disorder, volunteered to participate in the study, conceived for the first time through at least one of the ARTs (ART group), and conceived naturally without any treatment for the first time (spontaneous group) were included in this study.

Study flow diagram is presented in Figure 1.

\section{Data Collection Tools}

Data were collected using a sociodemographic Questionnaire/ Personal Identification Form, Prenatal Self-Evaluation Questionnaire (PSEQ), and Depression, Anxiety, Stress scale (DASS).

The personal identification form was used to determine the descriptive characteristics of the women. PSEQ was used to evaluate their adaptation to pregnancy, and DASS was used to evaluate their depression, anxiety, and stress levels. The Personal Identification Form- $2^{\text {nd }}$ Trimester and Personal Identification Form- $3^{\text {rd }}$ Trimester were used to evaluate changes that may occur in the second and third trimesters, respectively.

The PSEQ was developed by Ledermanin 1979 to evaluate adaptation to motherhood in antenatal women and was adapted into Turkish by Beydağ and Mete (14). The PSEQ has a 4-point Likert scale with 79 items and seven subscales. The total scores range from 79 to 316 points. Lower scores indicate better adaptation to pregnancy, while higher scores mean poor adaptation (14).

The DASS was developed by Lovibond and Lovibond (15) to measure the negative emotional states of depression, anxiety, and stress, and it was adapted into Turkish by Akın and Çetin (16). The DASS is a 42-item questionnaire that includes three (depression, anxiety, and stress) self-reporting scales. High scores from each dimension indicate a problem about the corresponding state (16).

\section{Statistical Analysis}

Statistical analyses were performed using SPSS 21.0 for Windows (IBM Corp., Armonk, NY, USA). Number, percentage, mean, standard deviation, chi-square, Independent samples t-test, and One-Way variance analysis were used in the analysis of data. The significance level was determined at a 95\% confidence interval and $\mathrm{p}<0.05$.

\section{Results}

The mean age of the participants (ART: $33.0 \pm 4.38$ years; spontaneous: $28.76 \pm 4.52$ years) and their partners' mean age (ART: $35.94 \pm 5.01$; spontaneous: $32.24 \pm 4.95)(\mathrm{p}<0.001)$ were significantly higher in the ART group than in the spontaneous group. In terms of the gestational week, a significant difference was found in the spontaneous group (ART: 10.74 \pm 2.21 ; spontaneous: $11.4 \pm 1.57)$. No significant difference was found between the ART and spontaneous groups in the number of pregnancy $(\mathrm{t}=0.378)$, miscarriage $(\mathrm{t}=1.912)$, and abortion $(t=0.020),(p>0.05)$. Data on the descriptive characteristics of the participants are shown in Table 1 .

In the first trimester, the average scores in the ART group were higher in the spontaneous group $(\mathrm{p}<0.05)$. Moreover, the adaptation of the spontaneous groups to pregnancy is better than that of the ART group in the first trimester (Table 2).

As shown in Table 3, an evaluation of the ART and spontaneous groups separately reveals that the depression levels of the ART group were not significantly different among the trimesters, while the depression levels of the spontaneous group appear higher during the first trimester than during the second trimester. Moreover, infertility duration, infertility treatment duration, number of ART trials, duration of desire to have children, pregnancy loss experience, and cause of infertility did not affect pregnancy adaptation in all trimesters. 


\section{STUDY FLOW DIAGRAM}

Calculated by taking into consideration the number of women who have applied to the i̇stanbul University, İstanbul Faculty of Medicine, Department of Reproductive Endocrinology and Infertility in the last year and according to the effect size (w) and the two-tailed hypothesis method. Women sampled according to the highest values using the G-Power test with $a=0.05$ and $\beta=0.20$ in 1 degree of freedom according to Women who conceived through ART
ART group $(n=125)$ the effect widths

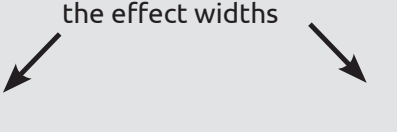

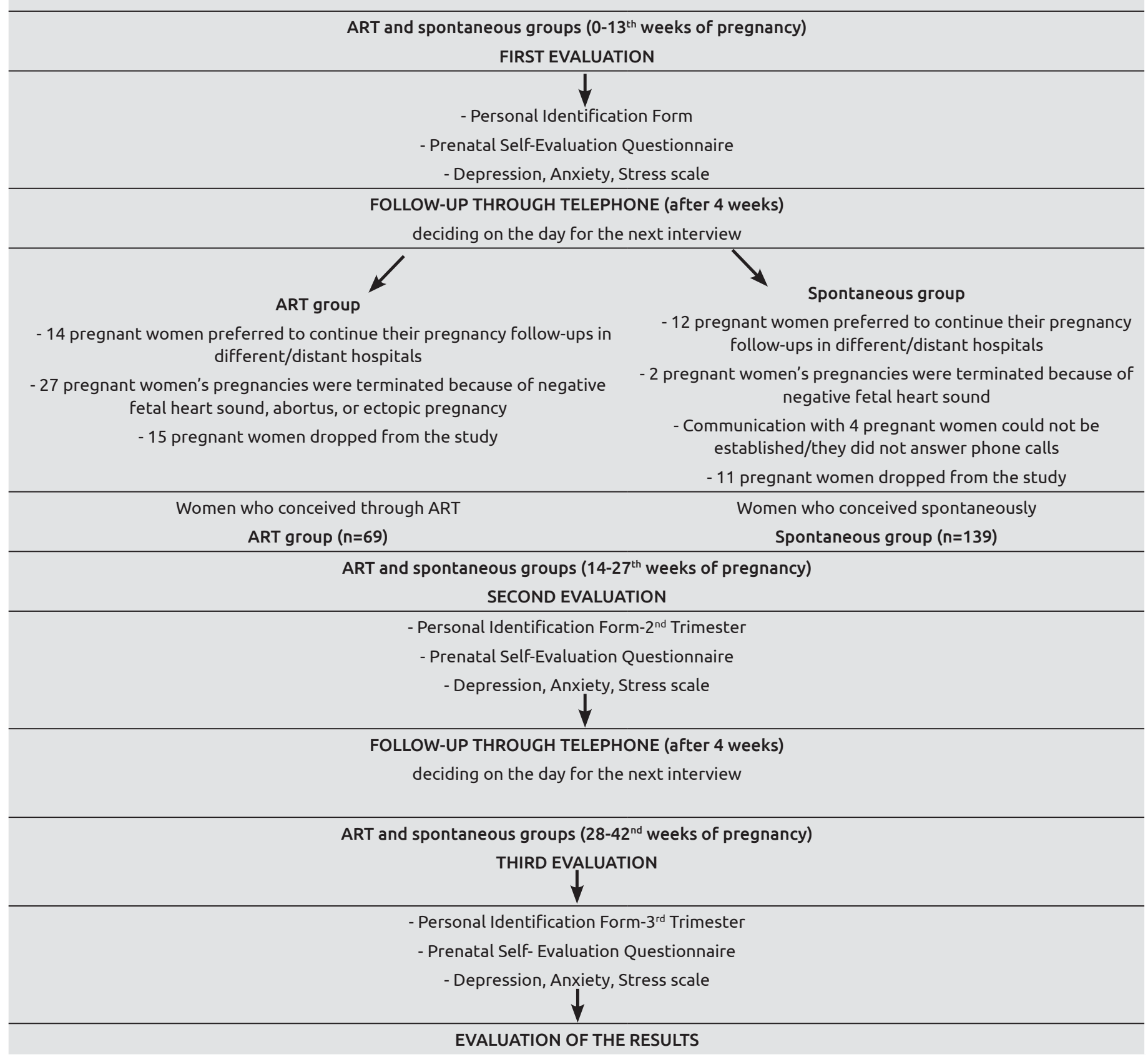

Figure 1. Study flow diagram

ART: Assisted reproductive treatment 
Table 1. Description and comparison of the participants $(n=208)$

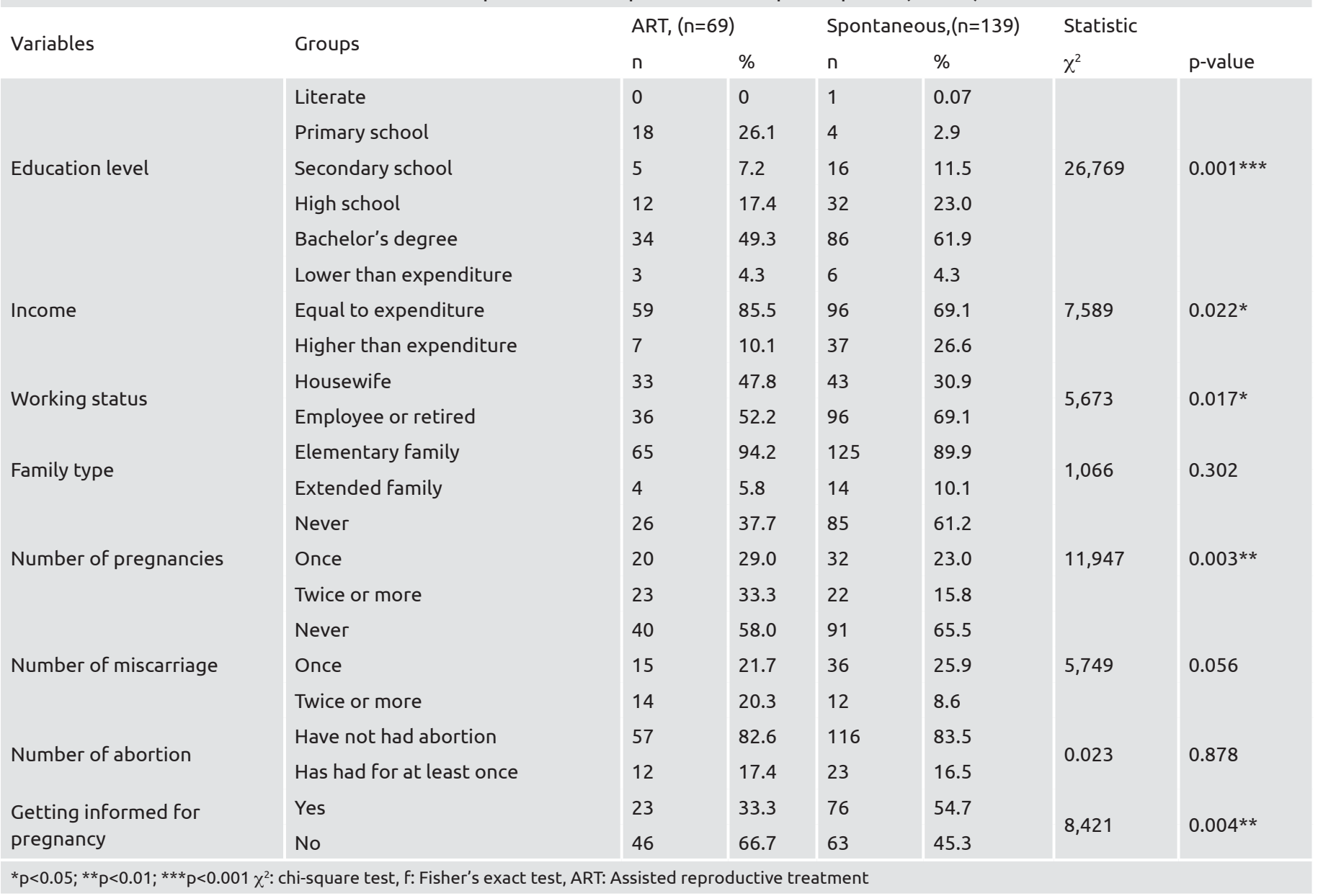

\section{Discussion}

In this study, the participants were 19-46 years old, which corresponds to the expectation that women who conceived through ART have a significantly higher average age than women

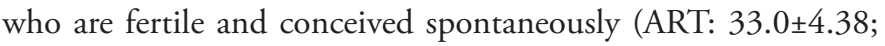
spontaneous: $28.76 \pm 4.52$ ). These results indicate the effect of age on infertility. It was also expected that the average age of partners of women who conceived through ART is significantly higher than those who conceived spontaneously. The guideline published by the American College of Obstetricians and Gynaecologists (ACOG) stated that the fertility of women and men decreased with age, emphasizing that age was a major factor of infertility (17).

Studies have emphasized the importance of prenatal care, and arranging training during this period to increase physical and psychological adaptation of the pregnant woman is necessary (18). While $66.7 \%$ of the pregnant women in the ART group did not receive any information, $54.7 \%$ of the pregnant women of the spontaneous group were informed about pregnancy. The women in the spontaneous group were thought to be more open to education considering their younger age and higher education levels. Despite the older age and lower education levels of women who are not well informed in the ART group, we think that the intensive knowledge they have received during the ART process may be effective in increasing consciousness.

In the comparison of total PSEQ scores, the spontaneous group demonstrated better adaptation than did the ART group during the first trimester. Women who conceived with moral and material difficulties may find it difficult to believe the pregnancy, so they may find themselves having constant repetitive pregnancy tests, ultrasound imaging, and examinations (19). This finding will inevitably contribute to the literature.

In the evidence-based guideline published by the European Society of Human Reproduction and Embryology (ESHRE), women who conceived through in vitro fertilization/intracytoplasmic sperm injection (IVF/ICSI) were reported to have no worse depression symptoms compared with women who conceived spontaneously (level of evidence, A) and that no difference was found between the groups, or the symptoms of depression were lower for women who conceived after treatment (20). In this study, the ART group showed milder depressive symptoms than the spontaneous group. This situation was interpreted by HarfKashdaei and Kaitz (21) as "enjoying the success" achieved after a long struggle with ART. These results can also be explained 
Table 2. Comparison of groups in total and subscales scores of the Prenatal Self-Evaluation Questionnaire ( $\mathrm{n=208)}$

\begin{tabular}{|c|c|c|c|c|c|c|c|}
\hline \multirow{2}{*}{ Mean } & & \multicolumn{2}{|c|}{ ART $(n=69)$} & \multicolumn{2}{|c|}{ Spontaneous ( $n=139)$} & \multirow{2}{*}{ Test value ( $(t)$} & \multirow{2}{*}{ p-value } \\
\hline & & SD & Mean & SD & & & \\
\hline \multirow{2}{*}{$\begin{array}{l}\text { Sense of well-being for } \\
\text { baby and self }\end{array}$} & $1^{\text {st }}$ trimester & 30.29 & 6.55 & 21.58 & 6.28 & 9,283 & $0.001 * * *$ \\
\hline & $3^{\text {rd }}$ trimester & 28.02 & 6.20 & 22.22 & 6.09 & 6,429 & $0.001 * * *$ \\
\hline \multirow{2}{*}{ Acceptance of pregnancy } & $1^{\text {st }}$ trimester & 24.68 & 6.62 & 20.09 & 5.58 & 4,947 & $0.001 * * *$ \\
\hline & $3^{\text {rd }}$ trimester & 16.86 & 2.81 & 18.79 & 4.61 & 3,745 & $0.001 * * *$ \\
\hline \multirow{3}{*}{$\begin{array}{l}\text { Identification of a } \\
\text { motherhood role }\end{array}$} & $1^{\text {st }}$ trimester & 22.68 & 4.65 & 23.23 & 4.63 & 0.804 & 0.423 \\
\hline & $2^{\text {nd }}$ trimester & 21.38 & 3.83 & 22.88 & 4.80 & 2,264 & $0.025^{*}$ \\
\hline & $3^{\text {rd }}$ trimester & 20.75 & 3.96 & 22.58 & 4.33 & 2,938 & $0.004 * *$ \\
\hline Preparation for labor & $1^{\text {st }}$ trimester & 18.55 & 4.23 & 19.32 & 5.02 & 1,164 & 0.246 \\
\hline \multirow[t]{2}{*}{ Fear of labor } & $2^{\text {nd }}$ trimester & 17.57 & 4.25 & 19.59 & 4.41 & 3,157 & $0.002 * *$ \\
\hline & $3^{\text {rd }}$ trimester & 25.29 & 5.13 & 19.14 & 3.89 & 8,794 & $0.001 * * *$ \\
\hline \multirow{3}{*}{$\begin{array}{l}\text { Relationship with her } \\
\text { mother }\end{array}$} & $1^{\text {st }}$ trimester & 15.07 & 5.09 & 15.47 & 4.91 & 0.540 & 0.590 \\
\hline & $2^{\text {nd }}$ trimester & 14.73 & 6.42 & 15.45 & 5.80 & 0.815 & 0.416 \\
\hline & $3^{\text {rd }}$ trimester & 14.33 & 4.80 & 15.06 & 4.98 & 1,000 & 0.319 \\
\hline \multirow{3}{*}{$\begin{array}{l}\text { Relationship with her } \\
\text { partner }\end{array}$} & $1^{\text {st }}$ trimester & 14.74 & 4.36 & 14.72 & 4.33 & 0.031 & 0.975 \\
\hline & $2^{\text {nd }}$ trimester & 13.90 & 3.67 & 14.63 & 4.66 & 1,240 & 0.217 \\
\hline & $3^{\text {rd }}$ trimester & 13.91 & 3.28 & 14.74 & 4.52 & 1,503 & 0.135 \\
\hline Total scores & $1^{\text {st }}$ trimester & 142.41 & 19.91 & 134.17 & 23.37 & 2,508 & $0.013^{*}$ \\
\hline
\end{tabular}

Table 3. Comparison of Depression, Anxiety. Stress Scale scores by groups and trimesters

\begin{tabular}{|c|c|c|c|c|c|c|c|c|c|}
\hline \multirow{2}{*}{ DASS } & \multirow{2}{*}{ Groups } & \multicolumn{2}{|c|}{$1^{\text {st }}$ Trimester } & \multicolumn{2}{|c|}{$2^{\text {nd }}$ Trimester $^{\mathrm{b}}$} & \multicolumn{2}{|c|}{$3^{\text {rd }}$ Trimester } & \multirow{2}{*}{ Test value (F) } & \multirow{2}{*}{ p-value } \\
\hline & & Mean & SD & Mean & SD & Mean & $\mathrm{SD}$ & & \\
\hline \multirow{3}{*}{ Depression } & ART $(n=69)$ & 3.36 & 4.26 & 3.13 & 4.74 & 3.71 & 5.34 & 0.393 & 0.676 \\
\hline & Spontaneous ( $n=139)$ & 5.37 & 5.75 & 3.83 & 4.50 & 4.68 & 4.33 & 6.319 & $0.002^{* *}, a>b$ \\
\hline & Total $(n=208)$ & 4.70 & 5.38 & 3.60 & 4.58 & 4.36 & 4.70 & 4.830 & $0.008^{* *}, a>b$ \\
\hline \multirow{3}{*}{ Anxiety } & ART $(n=69)$ & 10.12 & 4.83 & 5.55 & 5.26 & 12.46 & 6.67 & 37.552 & $0.001^{* * *}, c>a>b$ \\
\hline & Spontaneous ( $n=139)$ & 7.91 & 5.79 & 6.73 & 5.66 & 9.19 & 5.44 & 12.888 & $0.001^{* * *}, c>a, b$ \\
\hline & Total $(n=208)$ & 8.64 & 5.58 & 6.34 & 5.55 & 10.28 & 6.06 & 41.632 & $0.001^{* * *}, c>a>b$ \\
\hline \multirow{3}{*}{ Stress } & ART $(n=69)$ & 15.80 & 6.62 & 9.72 & 7.83 & 21.81 & 8.05 & 65.155 & $0.001^{* * *}, c>a>b$ \\
\hline & Spontaneous ( $n=139)$ & 11.88 & 6.88 & 9.86 & 6.63 & 12.66 & 5.97 & 11.829 & $0.001^{* * *}, a, c>b$ \\
\hline & Total $(n=208)$ & 13.18 & 7.03 & 9.81 & 7.03 & 15.70 & 7.98 & 53.411 & $0.00^{* * *}, c>a>b$ \\
\hline
\end{tabular}

by several factors such as the end of material and spiritual exhaustion, disappearance of social pressure, or end of a difficult treatment period.

Moreover, ESHRE (20) reported that anxiety levels of pregnant women after IVF/ICSI may be higher than that of women who conceived spontaneously (level of evidence, B). Related qualitative studies have also emphasized that miscarriage risk increases the anxiety levels in the first trimester of the women who conceived through ART, that their anxiety levels decreased when they felt the baby's movements in the second trimester, that 
the fear of labor and thought of deficiencies in the baby increased the anxiety levels, and that the pregnant women experienced nightmares in the third trimester $(13,19)$.

In the present study, the anxiety levels of the ART group are higher than those of the spontaneous group. This result is in line with the literature. In a comparative study, Baor and Soskolne (22) revealed that the ART group had higher stress levels than the spontaneous group. Similar results were also reported by Darwiche et al. (23) who compared pre-pregnancies before Down syndrome screening in the first trimester. Similarly, in the present study, the stress levels of the ART group were higher than those of the spontaneous group.

In this study, the participants were 19-46 years old, which corresponds to the expectation that women who conceived through ART have a significantly higher average age than women who are fertile and conceived spontaneously (ART: 33.0 44.38; spontaneous: $28.76 \pm 4.52$ ). These results indicate the effect of age on infertility. It was also expected that the average age of partners of women who conceived through ART is significantly higher than those who conceived spontaneously. The guideline published by the ACOG stated that the fertility of women and men decreases with age, emphasizing that age is a major factor of infertility (17).

Studies have emphasized the importance of prenatal care, and arranging training during this period to increase physical and psychological adaptation of the pregnant woman is necessary (18). While $66.7 \%$ of the pregnant women in the ART group did not receive any information, $54.7 \%$ of the pregnant women of the spontaneous group were informed about pregnancy. The women in the spontaneous group were thought to be more open to education considering their younger age and higher education levels. Despite the older age and lower education levels of women who are not well informed in the ART group, we think that the intensive knowledge they have received during the ART process may be effective in increasing consciousness.

In the comparison of total PSEQ scores, the spontaneous group demonstrated better adaptation than did the ART group during the first trimester. Women who conceived with moral and material difficulties may find it difficult to believe the pregnancy, so they may find themselves having constant repetitive pregnancy tests, ultrasound imaging, and examinations (19). This finding will inevitably contribute to the literature.

In the evidence-based guideline published by ESHRE, women who conceived through IVF/ICSI were reported to have no worse depression symptoms compared with women who conceived spontaneously (level of evidence, A) and that no difference was found between the groups, or the symptoms of depression were lower for women who conceived after treatment (20). In this study, the ART group showed milder depressive symptoms than the spontaneous group. This situation was interpreted by HarfKashdaei and Kaitz (21) as "enjoying the success" achieved after a long struggle with ART. These results can also be explained by several factors such as the end of material and spiritual exhaustion, disappearance of social pressure, or end of a difficult treatment period.

In the comparison of total PSEQ scores, the spontaneous group demonstrated better adaptation than did the ART group during the first trimester. Women who conceived with moral and material difficulties may find it difficult to believe the pregnancy, so they may find themselves having constant repetitive pregnancy tests, ultrasound imaging, and examinations (19). This finding will inevitably contribute to the literature.

In the evidence-based guideline published by the ESHRE, women who conceived through IVF/ICSI were reported to have no worse depression symptoms compared with women who conceived spontaneously (Level of evidence, A) and that no difference was found between the groups, or the symptoms of depression were lower for women who conceived after treatment (20). In this study, the ART group showed milder depressive symptoms than the spontaneous group. This situation was interpreted by Harf-Kashdaei and Kaitz (21) as "enjoying the success" achieved after a long struggle with ART (21). These results can also be explained by several factors such as the end of material and spiritual exhaustion, disappearance of social pressure, or end of a difficult treatment period.

\section{Study Limitations}

In the present study, the anxiety levels of the ART group are higher than those of the spontaneous group. This result is in line with the literature. In a comparative study, Baor and Soskolne (22) revealed that the ART group had higher stress levels than the spontaneous group. Similar results were also reported by Darwiche et al. (23) who compared pre-pregnancies before Down syndrome screening in the first trimester. Similarly, in the present study, the stress levels of the ART group were higher than those of the spontaneous group.

\section{Conclusion}

The results of this study indicate that pregnancy adaptations of the spontaneous group are better than those of the ART group in the first trimester. Moreover, the anxiety and stress levels of the ART group were higher than those of the spontaneous group in the first and third trimesters. In line with these results, psychosocial support programs should be organized for women who conceived through ART in infertility clinics. In addition, routine pregnancy monitoring should cover the psychosocial evaluation of pregnant women, including adjustment, depression, anxiety, and stress. Further studies with a larger number of participants (women and their partners) will contribute to developing specific guidelines about psychosocial care. These guidelines will help nurses in providing psychosocial support to patients, which will eventually improve the quality of care.

\section{Ethics}

Ethics Committee Approval: Ethical approval was obtained from the Ethics Committee of Medipol University Faculty of Medicine (approval no: 108400987-292, date: 11.05.2015). 
Peer-review: Externally peer reviewed.

Financial Disclosure: The author declared that this study received no financial support.

\section{References}

1. Dilek N, Beji NK. Determining the emotional reactions of couples undergoing assisted reproductive procedures. HEAD 2012;9:24-9.

2. Yılmaz T, Oskay ÜY. Methods to cope with infertility stress and nursing attitudes. HSP 2015;2:100-12.

3. HaCohen N, Amir D, Wiseman H. Women's narratives of crisis and change: Transitioning from infertility to pregnancy. J Health Psychol 2018;23:720-30.

4. Bayram GO. İnfertilitenin yaşam kalitesi ve evlilik uyumu üzerine etkisi. Istanbul Üniversitesi Sağlık Bilimleri Enstitüsü. Doktora Tezi; 2009.

5. Gameiro S, Moura-Ramos M, Canavarro MC, Soares I. Psychosocial adjustment during the transition to parenthood of Portuguese couples who conceived spontaneously or through assisted reproductive technologies. Res Nurs Health 2010;33:207-20.

6. Fisher JR, Hammarberg K, Baker HW. Assisted conception is a risk factor for postnatal mood disturbance and early parenting difficulties. Fertil Steril 2005;84:426-30.

7. Seven M, Akyüz A. An under-recognized factor in the development of postpartum depression: infertility. HEAD 2013;10:7-11.

8. Gourounti K. Psychological stress and adjustment in pregnancy following assisted reproductive technology and spontaneous conception: A systematic review. Women Health 2016;56:98-118.

9. Ataman H, Arslan H. Psycho-social care needs in pregnancies experienced naturally and pregnancies with as a result of infertility treatment. J Fam Soc 2010;6:75-86.

10. Ellison MA, Hall JE. Social stigma and compounded losses: qualityof-life issues for multiple-birth families. Fertil Steril 2003;80:405-14.

11. Monti F, Agostini F, Fagandini P, La Sala GB, Blickstein I. Depressive symptoms during late pregnancy and early parenthood following assisted reproductive technology. Fertil Steril 2009;91:851-7.

12. Lepecka-Klusek C, Jakiel G. Difficulties in adaptation to pregnancy following natural conception or use of assisted reproduction techniques: a comparative study. Eur J Contracept Reprod Health Care 2007;12:51-7.
13. Redshaw M, Hockley C, Davidson LL. A qualitative study of the experience of treatment for infertility among women who successfully became pregnant. Hum Reprod 2007;22:295-304.

14. Beydağ KD, Mete S. Prenatal kendini değerlendirme ölçeğinin geçerlik ve güvenirlik çalışması. Journal of Anatolia Nursing and Health Sciences 2008;11:16-24.

15. Lovibond PF, Lovibond SH. The structure of negative emotional states: comparison of the Depression Anxiety Stress Scales (DASS) with the Beck Depression and Anxiety Inventories. Behav Res Ther 1995;33:335-43.

16. Akın A, Çetin B. The depression, anxiety and stress scale (DASS): The study of validity and reliability. Educational Sciences: Theory and Practice 2007;7:260-8.

17. The American College of Obstetricians and Gynecologists- ACOGTreating Infertility. 2017; [cited 2016 Des 14]. Available from: https://www.acog.org/Patients/FAQs/Treating-Infertility

18. Demirbaş H, Kadıoğlu H. Adaptation of pregnancy in prenatal period women and factors associated with adaptation. MÜSBED 2014;4:200-6.

19. Covington SN, Burns LH. Pregnancy after infertility. In: Infertility CounselingA Comprehensive Handbook for Clinicians. 2nd ed. UK: Cambridge University Press; 2006. p. 440-58.

20. The European Society of Human Reproduction and Embryology - ESHRE. Psychology and Counselling Guideline Development Group, Routine psychosocial care in infertility and medically assisted reproduction A guide for fertility staff. 2015; [cited 2016 Jan 20]. Available from: https://www.eshre.eu/Guidelines-and-Legal/ Guidelines/Psychosocial-care-guideline.aspx

21. Harf-Kashdaei E, Kaitz M. Antenatal moods regarding self, baby, and spouse among women who conceived by in vitro fertilization. Fertil Steril 2007;87:1306-13.

22. Baor L, Soskolne V. Mothers of IVF and spontaneously conceived twins: a comparison of prenatal maternal expectations, coping resources and maternal stress. Hum Reprod 2010;25:1490-6.

23. Darwiche J, Lawrence C, Vial Y, Wunder D, Stiefel F, Germond M, et al. Anxiety and psychological stress before prenatal screening in firsttime mothers who conceived through IVF/ICSI or spontaneously. Women Health 2014;54:474-85. 